\title{
Nucleolar activity during larval development of Myrmeleon uniformis Navas, 1920 (Neuroptera, Myrmeleontidae)
}

\author{
C.A. Pacheco ${ }^{1}$, K.C.C. Alevi ${ }^{2}$, T.L. Silva ${ }^{2}$, M.T.V. Azeredo-Oliveira ${ }^{2}$, \\ C.R. Ceron ${ }^{3}$ and M.K.H. Kobayashi ${ }^{2}$
}

${ }^{1}$ Centro Universitário do Norte Paulista, São José do Rio Preto, SP, Brasil

${ }^{2}$ Laboratório de Biologia Celular, Departamento de Biologia,

Instituto de Biociências, Letras e Ciências Exatas,

Universidade Estadual Paulista "Júlio de Mesquita Filho",

São José do Rio Preto, SP, Brasil

${ }^{3}$ Laboratório de Genética Bioquímica, Departamento de Biologia,

Instituto de Biociências, Letras e Ciências Exatas,

Universidade Estadual Paulista "Júlio de Mesquita Filho",

São José do Rio Preto, SP, Brasil

Corresponding author: K.C.C. Alevi

E-mail: kaiochaboli@hotmail.com

Genet. Mol. Res. 13 (3): 5154-5158 (2014)

Received July 10, 2013

Accepted January 28, 2014

Published July 7, 2014

DOI http://dx.doi.org/10.4238/2014.July.7.8

\begin{abstract}
It has been reported in the literature that the Malpighian tubules of Neuroptera in the third instar undergo drastic histological changes, when they stop functioning in osmoregulation and start to secrete silk fibers for a cocoon. Therefore, to increase our knowledge about these cellular alterations that occur in the larvae of Neuroptera, we analyzed the cells that constitute the Malpighian tubules of each larval instar of the species Myrmeleon uniformis, with emphasis on nucleolar activity. Malpighian tubules, after being removed, were fixed on a slide using liquid nitrogen and stained by silver impregnation. In
\end{abstract}


addition, total protein of the tubules was quantified. By analyzing the cells in the first instar larval stage, we observed only two silver-stained nucleolar regions. In cells of second instar larvae, there was an increase in the number of stained regions, and in the third instar, the number of nucleolar regions was very large. Agarose gel electrophoresis indicated that third instar larvae had high synthetic activity, where the total amount of proteins was larger in third instar stage than in the other larval stages. Furthermore, the most abundant proteins displayed molecular weights of about $32-43 \mathrm{kDa}$ and were probably precursors of silk fibers. Thus, the results obtained showed that nucleolar alterations occur in the cells of the Malpighian tubules of larval instars of M. uniformis and this is directly related to the production of silk fibers used by the pupa to ensure the completion of metamorphosis.

Key words: Cytochemical; Myrmeleon uniformis; Silver impregnation; Nucleolus

\section{INTRODUCTION}

The tribe Myrmeleontini includes nine genera and over 200 species (Qing-Bin and Xin-Li, 2012). The genus Myrmeleon was proposed by Linnaeus in 1767 and currently consists of 176 species (Stange, 2004).

These insects, popularly known as antlions, are holometabolous, i.e., after the eggs hatch, they pass through larval (L1, L2, L3) pupal, and imago stages (Gilbert, 1994). The larvae are known for their strategy of building funnel-shaped traps in the sandy soil to capture their prey (Napolitano, 1998).

In the third instar larval stage of Neuroptera (L3), when they reach the pre-pupal stage, the Malpighian tubules cease to perform the function of osmoregulation and undergo drastic histological changes to start the production of the precursors of silk fibers for the formation of the cocoon (Spiegler, 1962; Wigglesworth, 1972).

Therefore, to increase our knowledge about these cellular alterations that occur in the larvae of Neuroptera, we analyzed the cells that constitute the Malpighian tubules of each larval instar (L1, L2, L3) of the species Myrmeleon uniformis, with emphasis on nucleolar activity.

\section{MATERIAL AND METHODS}

Specimens of M. uniformis were collected in Barra do Monjolo, located in Minas Gerais, Brazil. These larvae were classified into L1, L2, and L3 according to Popov (1984). Malpighian tubules, after being removed, were fixed on the slide with liquid nitrogen. The specimens were then subjected to cytogenetic analysis using the silver impregnation technique (Howell and Black, 1980). In addition, total proteins of the tubules were quantified by the method of Lowry et al. (1951). The samples were macerated in $0.0625 \mathrm{M}$ buffer, $\mathrm{pH} 6.9$, $\beta$ mercaptoethanol at $1 \%$ and SDS at $2 \%$, and denatured in boiling water $\left(100^{\circ} \mathrm{C}\right)$, for $5 \mathrm{~min}-$ utes. Polyacrylamide gel at $9 \%$ and stacking gel at $4 \%$ were utilized at $100 \mathrm{~V}$, for $4 \mathrm{~h}$. The gel 
was placed in TCA fixing solution $(15 \%)$ at $4^{\circ} \mathrm{C}$ overnight. After this period it was washed in distilled water, in order to remove the excess of TCA, and colored with Coomassie brilliant blue R 250 ( $0.2 \%$ ethanol and glacial acetic acid), for $24 \mathrm{~h}$. The gel was then discolored with a discoloring/preserving solution made up of water/ethanol/acetic acid (3:1:1) and glycerol at $10 \%$. The gel was dried following the method of Ceron et al. (1992).

\section{RESULTS AND DISCUSSION}

The cytogenetic technique of silver impregnation allows the identification of the nucleolus because silver ions bind strongly to the nucleolar proteins C23 and B23 (Ochs et al., 1983; Ochs and Busch, 1984; Casseb-Hassan and Azeredo-Oliveira, 1999). The cells in the first instar larval stage showed only two silver-stained nucleolar regions (Figure 1A). The cells of second instar larvae showed an increased number of silver-stained areas (Figure 1B) and those of third instar larvae a very large number of these nucleolar regions (Figure 1C).
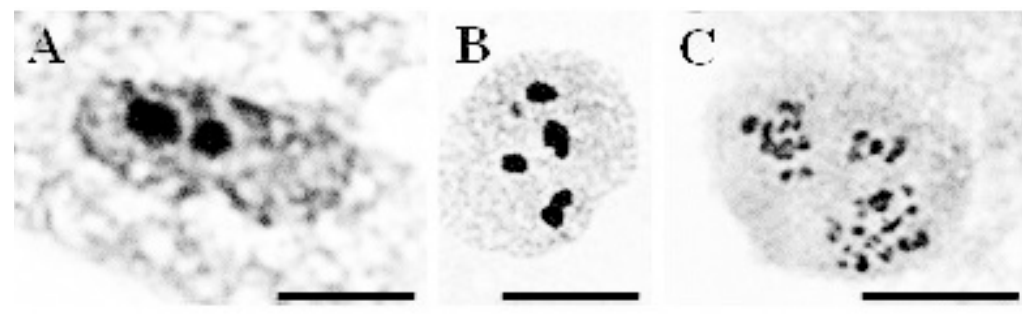

Figure 1. Malpighian tubules of larval instars of Myrmeleon uniformis stained with silver ion impregnation. Note that the amount of nucleolar corpuscles were increasing according to the nymphal instars, L1 (A), L2 (B), L3 (C). Bar: $10 \mu \mathrm{m}$.

The nucleolus is a cellular structure that plays an important role in protein synthesis and is thus essential for the cell to live (Lewis et al., 2007). This cellular component is responsible for the biogenesis of ribosomes, which occurs through many events involving the transcription of ribosomal RNA genes (rRNA), pre-rRNA processing and assembly of preribosomal particles (Scheer et al., 1997).

We observed that nucleolar staining in larvae increased progressively from the first to second to third instar. According to Tavares and Azeredo-Oliveira (1997), the size and number of nucleoli and nucleolar bodies depend on the functional characteristics of the cells and may thereby reflect differences in metabolic and functional activities. Alevi et al. (2013) reported differences in transcriptional activity between two triatomine species according nucleolar staining.

Agarose gel electrophoresis showed that the total amount of proteins was larger in larvae of the third instar compared to other larval stages, indicating high synthetic activity in the late larval stage. Furthermore, the most abundant proteins displayed molecular weights of about $32-43 \mathrm{kDa}$ and were probably precursors of silk fibers (Figure 2).

Thus, the results obtained showed that nucleolar alterations occurred in the cells of the Malpighian tubules of larval instars of M. uniformis. These results provide evidence of an increase in synthetic activity, indicated by the increasing number of nucleolar bodies and total proteins during larval development. These changes can be related to the production of silk 
fibers, essential for the formation of the cocoon, which confers protection to the body during the pupal stage for the final changes to complete metamorphosis.

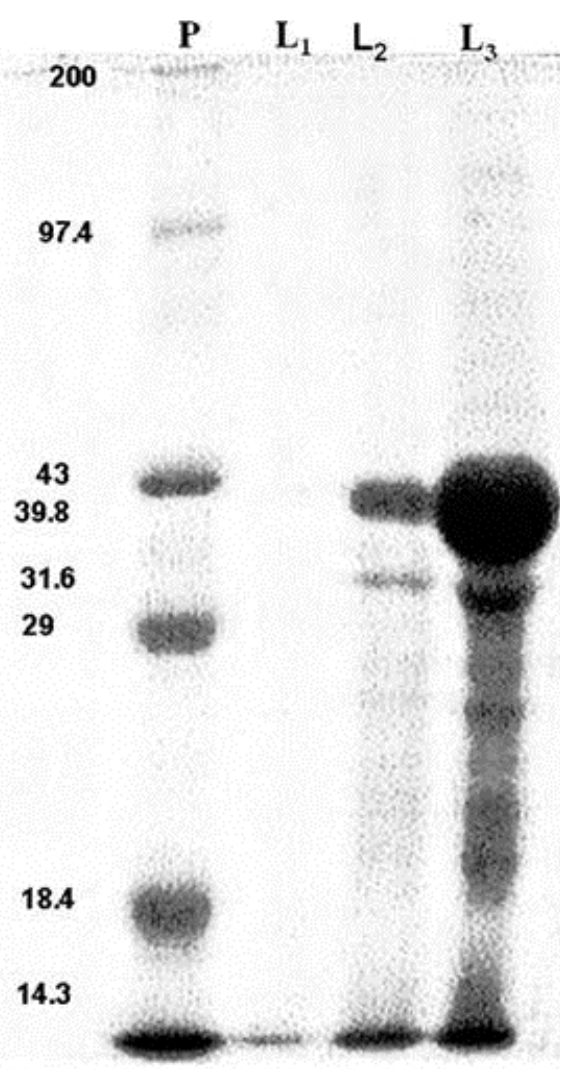

Figure 2. Quantification of total protein in the Malpighian tubules of the three nymphal instars of Myrmeleon uniformis. Note that L3 showed higher quantity of total protein and that the protein expressed more was between 32-43 kDa. Lane $P=$ proteins with molecular weight already established. Lane $L 1=$ first-instar larval stage. Lane $L 2=$ second-instar larval stage. Lane $L 3=$ third-instar larval stage.

\section{ACKNOWLEDGMENTS}

Research supported by Fundação de Amparo à Pesquisa do Estado de São Paulo (FAPESP), Conselho Nacional de Desenvolvimento Científico e Tecnológico (CNPq) and Fundação de Apoio à Pesquisa e Extensão de Rio Preto (FAPERP).

\section{REFERENCES}

Alevi KCC, Mendonça PP, Pereira NP, Rosa JA, et al. (2013). Análise das possíveis Regiões Organizadoras Nucleolares e da atividade nucleolar em Triatoma melanocephala e T. lenti, importantes vetores da doença de Chagas. Rev. Ciênc. Farm. Básica Apl. 34: 417-421.

Casseb-Hassan PM and Azeredo-Oliveira MTV (1999). Estrutura nucleolar e impregnação por íons prata. HB Cient. 6 : 172-178. 
Ceron CR, Santos JR and Bicudo HEMC (1992). The use of gelatin to dry cellophane wound slab gels in an embroidering hoop. Rev. Bras. Gen. 15: 201-203.

Gilbert C (1994). Form and function of stemmata in larvae of holometabolous insects. Annu. Rev. Entomol. 39: 323-349.

Howell WM and Black DA (1980). Controlled silver-staining of nucleolus organizer regions with a protective colloidal developer: a 1-step method. Experientia 36: 1014-1015.

Lewis MS, Pikaard DJ, Nasrallah M, Doelling JH, et al. (2007). Locus-specific ribosomal RNA gene silencing in nucleolar dominance. PLoS One 2: e815.

Lowry OH, Rosebrough NJ, Farr AL and Randall RJ (1951). Protein measurement with the Folin phenol reagent. J. Biol. Chem. 193: 265-275.

Napolitano JF (1998). Predatory behavior of a pit-marking antlion, Myrmelon mobilis (Neuroptera: Myrmeleontidae). Fla. Entomol. 81: 562-566.

Ochs RL and Busch H (1984). Further evidence that phosphoprotein C23 (110 kD/pI 5.1) is the nucleolar silver staining protein. Exp. Cell Res. 152: 260-265.

Ochs R, Lischwe M, O’Leary P and Busch H (1983). Localization of nucleolar phosphoproteins B23 and C23 during mitosis. Exp. Cell Res. 146: 139-149.

Popov A (1984). The Development of Myrmecaelurus trigammus Pall. (Myrmeleonidae). In: Progress in World's Neuroptelorogy (Gepp J, Aspock H and Holzel H, eds.). Editora Graz, 249-251.

Qing-Bin Z and Xin-Li W (2012). Elliptic Fourier Analysis of the Wing Outline Shape of Five Species of Antlion (Neuroptera: Myrmeleontidae: Myrmeleontini). Zool. Stud. 51: 399-405.

Scheer U, Xia B, Merkert H and Weisenberger D (1997). Looking at Christmas trees in the nucleolus. Chromosoma 105: 470-480.

Spiegler PE (1962). The origin and nature of the adhesive substance in larvae of the genus Chrysopa (Neuroptera: Chrysopidae). Ann. Entomol. Soc. Am. 55: 69-77.

Stange LA (2004). A systematic catalog, bibliography, and classification of the world antlions (Insecta: Neuroptera: Myrmeleontidae). Memoirs Amer. Entomol. Inst. 74: 1-565.

Tavares MG and Azeredo-Oliveira MTV (1997). Pattern of nucleolar activity during spermatogenesis in triatomines (Heteroptera, Reduviidae) as analyzed by silver staining. Cytobios 89: 93-103.

Wigglesworth VB (1972). The Principles of Insect Physiology. Chapman and Hall, London. 